\title{
Idarucizumab - nowy poziom terapii przeciwkrzepliwej. Opis leczenia powikłań krwotocznych u 93-letniej chorej
}

\author{
Idarucizumab: a new level of anticoagulation therapy. \\ Description of the treatment of bleeding in 93-year-old patient
}

\author{
Kamilla Wesołowska ${ }^{1}$, Agnieszka Woronowicz-Chróściel ${ }^{1}$, \\ Maciej Kluk ${ }^{1}$, Beata Wożakowska-Kapłon ${ }^{1,2}$ \\ ${ }^{1}$ I Klinika Kardiologii i Elektroterapii Świętokrzyskiego Centrum Kardiologii w Kielcach \\ ${ }^{2}$ Wydział Lekarski i Nauk o Zdrowiu Uniwersytetu Jana Kochanowskiego w Kielcach
}

\section{Streszczenie}

Idarucizumab to fragment przeciwciała monoklonalnego, które ma silne powinowactwo do eteksylanu dabigatranu i się z nim łączy, powodując szybkie zahamowanie jego przeciwzakrzepowego działania. Iniekcja idarucizumabu u chorych stosujących eteksylan dabigatranu w krótkim czasie przywraca ogólnoustrojowe krzepnięcie krwi i umożliwia powtórne tworzenie fibryny, która odgrywa kluczową rolę w mechanizmie krzepnięcia krwi.

Słowa kluczowe: idarucizumab, dabigatran, antidotum, krwawienie z przewodu pokarmowego

Folia Cardiologica 2016; 11, 6: 554-556

\section{Wstęp}

Idarucizumab to fragment przeciwciała monoklonalnego, które ma silne powinowactwo do eteksylanu dabigatranu i łączy się z nim w stosunku molarnym 1:1 (nawet z cząsteczkami dabigatranu związanymi już z trombiną). Powoduje to szybkie zahamowanie działania przeciwzakrzepowego eteksylanu dabigatranu. Podanie idarucizumabu u chorych stosujących eteksylan dabigatranu w krótkim czasie przywraca ogólnoustrojowe krzepnięcie krwi i umożliwia powtórne tworzenie fibryny, która odgrywa kluczową rolę w mechanizmie krzepnięcia krwi.

\section{Opis przypadku}

Kobieta w wieku 93 lat, z wywiadem nadciśnienia tętniczego, po przebytym udarze niedokrwiennym mózgu, z niedowładem prawostronnym, z chorobą niedokrwienną serca oraz utrwalonym migotaniem przedsionków (od miesiąca przyjmowała eteksylan dabigatranu w dawce $110 \mathrm{mg} 2 \times /$ d.), obciążona wysokim ryzykiem powikłań zakrzepowo-zatorowych (7 pkt. w $\mathrm{CHA}_{2} \mathrm{DS}_{2}$-VASc; 3 pkt. w HAS-BLED), została skierowana do szpitala z powodu ciężkiego krwawienia z górnego odcinka przewodu pokarmowego (smoliste stolce i skrzepy krwi w stolcu). Chora zgłaszała narastające osłabienie, bóle w klatce piersiowej oraz uczucie dyskomfortu w podbrzuszu. W badaniu przedmiotowym stwierdzono cechy odwodnienia, wzdęcie brzucha. W badaniach biochemicznych przy przyjęciu do szpitala stwierdzono niedokrwistość - stężenie hemoglobiny ( $\mathrm{Hb}$ ) wynosiło 10,4 g/dl (norma 12,0-15,6 g/dl), znacznie obniżony był klirens kreatyniny $(\mathrm{CrCl}$, creatinine clearance) $-28,4 \mathrm{ml} / \mathrm{min}$ (norma 75,0-110,0 ml/min) oraz znacznie wydłużony czas częściowej tromboplastyny po aktywacji (APTT, activated partial thromboplastin time) - do 119,7 s (norma 26-40 s). Ostatnią dawkę dabigatranu chora przyjęła 6 godzin przed hospitalizacją. 
Tabela 1. Wybrane parametry laboratoryjne u opisywanej chorej

\begin{tabular}{lccccc}
\multicolumn{1}{c}{ Czas oznaczenia } & $\begin{array}{c}\text { Bezpośrednio } \\
\text { przed podaniem } \\
\text { idarucizumabu }\end{array}$ & $\begin{array}{c}\text { W 15. min. } \\
\text { od podania } \\
\text { idarucizumabu }\end{array}$ & $\begin{array}{c}\text { W 120. min. } \\
\text { od podania } \\
\text { idarucizumabu }\end{array}$ & $\begin{array}{c}\text { 7. doba } \\
\text { od podania } \\
\text { idarucizumabu }\end{array}$ & $\begin{array}{c}\text { 30. doba } \\
\text { od podania } \\
\text { idarucizumabu }\end{array}$ \\
laboratoryjne & 119,7 & 46,9 & 47,1 & 26,7 & 43,1 \\
$\begin{array}{l}\text { APTT [s] (n. 26,0-40,0 s) } \\
\text { CrCl [ml/min] }\end{array}$ & 28,4 & 35,0 & - & 37,0 & 40,0 \\
(n. $75,0-110,0 \mathrm{ml} / \mathrm{min})$ & 10,4 & 8,3 & - & 13,1 & 12,5 \\
$\mathrm{Hb}[\mathrm{g} / \mathrm{dl}]$ & & & (po podaniu 2 j. kkcz) &
\end{tabular}

APTT (activated partial thromboplastin time) - czas częściowej tromboplastyny po aktywacji; $\mathrm{CrCl}$ (creatinine clearance) - klirens kreatyniny; Hb - hemoglobina; kkcz - koncentrat krwinek czerwonych

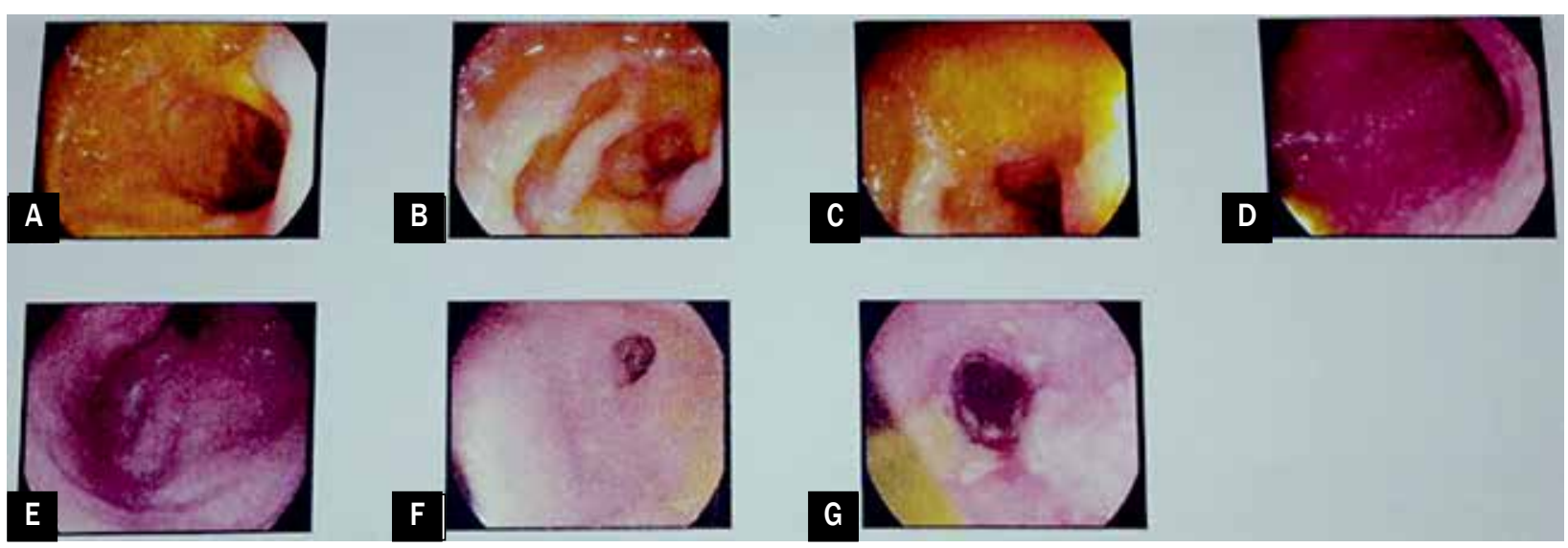

Rycina 1A-G. Badanie gastroduodenoskopowe - opuszka dwunastnicy wrzodowo zniekształcona z dwoma owrzodzeniami pokrytymi włóknikiem; brak cech aktywnego krwawienia

Przy przyjęciu do kliniki stan chorej pozostawał średnio ciężki; stwierdzono hipotonię $80 / 50 \mathrm{~mm} \mathrm{Hg}$, migotanie przedsionków z odpowiedzią komór około 90/min. W badaniu palpacyjnym brzuch był miękki z nieznaczną bolesnością w śródbrzuszu. Po konsultacji chirurgicznej zastosowano: płyny infuzyjne, pantoprazol we wlewie dożylnym, kwas traneksamowy oraz etamsylat droga dożylną.

Jednocześnie pacjentce podano 5 g idarucizumabu w 2 dawkach (2,5 g w objętości $50 \mathrm{ml}$ w szybkim [5-min] wlewie dożylnym, w odstępie 10 min między dawkami) w celu odwrócenia efektu przeciwkrzepliwego dabigatranu. W kontrolnych badaniach laboratoryjnych (w 15. i 30. min od podania wlewu) stwierdzono szybką normalizację wartości APTT wynoszącą 46,9 s w 20. minucie od podania drugiej dawki idarucizumabu (tab. 1) oraz poprawę stanu ogólnego już w pierwszych godzinach po podaniu wlewu. W trybie pilnym wykonano badanie gastroduodenoskopowe (ryc. 1), uwidaczniając owrzodzenie dwunastnicy bez cech aktywnego krwawienia do światła przewodu pokarmowego. Ze względu na stwierdzoną w drugiej dobie hospitalizacji znaczną niedokrwistość (Hb 8,3 g/dl) przetoczono u cho- rej 2 jednostki koncentratu krwinek czerwonych (kkcz) zgodnych grupowo. Po uzupełnieniu płynów poprawiły się parametry funkcji nerek $(\mathrm{CrCl} 35 \mathrm{ml} / \mathrm{min})$ i obserwowano normalizację APTT (26,7 s). W leczeniu zastosowano doustny preparat inhibitora pompy protonowej oraz eradykację Helicobacter pylori (metronidazol, amoksycylina). W kolejnych dobach stan chorej pozostawał stabilny. Ze względu na wysokie ryzyko udaru mózgu w 7 . dobie od incydentu krwawienia z przewodu pokarmowego ponownie włączono u pacjentki terapię dabigatranem (w dawce $2 \times 110 \mathrm{mg}$ ), uznając, że przeprowadzony proces eradykacji oraz terapia inhibitorem pompy protonowej zmniejszają ryzyko nawrotu kolejnego krwawienia z przewodu pokarmowego. Chora i rodzina zostali pouczeni o konieczności właściwego nawodnienia, kontroli parametrów wydolności nerek oraz obserwacji objawów mogących świadczyć o krwawieniu z przewodu pokarmowego. Dawka dabigatranu 2 razy 110 mg okazała się w badaniu RELY [1] bezpieczniejsza niż warfaryny w kontekście pierwszorzędowego punktu końcowego bezpieczeństwa. Powtórne inicjowanie terapii przeciwkrzepliwej należy uzależnić od ustalenia przyczyny krwawienia i jej usunięcia. W 30. dobie obserwacji 
prezentowanej pacjentki odnotowano stabilizację parametrów morfotycznych i nerkowych oraz wydłużony APTT.

\section{Podsumowanie}

Epizody krwawienia u chorych przyjmujących doustne antykoagulanty niebędące antagonistami witaminy K (NOAC, non-vitamin K antagonist oral anticoagulants) najczęściej wiążą się z pogorszeniem funkcji nerek, niekontrolowanym przyjmowaniem niesteroidowych leków przeciwzapalnych (NLPZ) lub skojarzonej terapii przeciwpłytkowej i przeciwkrzepliwej. Właściwe nawodnienie chorego, kontrola $\mathrm{CrCl}$ bądź przesączania kłębuszkowego oraz ostrzeżenie przed samowolnym przyjmowaniem leków zwiększających ryzyko krwawienia powinny być nieodłącznym elementem terapii za pomocą NOAC. Czasami krwawienie bywa pierwszym symptomem i ujawnia poważną chorobę przewodu pokarmowego w jej początkowej fazie. Powtórne inicjowanie terapii przeciwkrzepliwej należy uzależnić od ustalenia przyczyny krwawienia z przewodu pokarmowego i układu moczowo-płciowego (najczęstsze miejsca krwawienia), po jej usunięciu można wprowadzać powtórną terapię.

Zastosowany u prezentowanej chorej idarucizumab całkowicie odwrócił działanie eteksylanu dabigatranu w ciągu kilku minut. Podanie swoistego czynnika odwracającego działanie dabigatranu - poza przypadkami zagrażającego życiu lub nieopanowanego krwawienia - jest wskazane u dorosłych pacjentów leczonych produktem eteksylanu dabigatranu w przypadku, gdy istnieje konieczność wykonania nieplanowanego zabiegu chirurgicznego w trypie nagłym. Idarucizumab został zarejestrowany przez Europejską Agencję ds. Leków (EMA, European Medicines Agency) w listopadzie 2015 roku i pozostaje obecnie jedynym dostępnym antidotum dla doustnych antykoagulantów, mającym zastosowanie oczywiście jedynie u chorych leczonych dabigatranem.

\begin{abstract}
Idarucizumab is a fragment of a monoclonal antibody that has high affinity for dabigatran etexilate and binds to it, causing a rapid suppression of its anticoagulant effect. Idarucizumab infusion in patients treated with dabigatran etexilate quickly restores systemic blood coagulation and enables the re-formation of fibrin that plays a key role in the mechanism of blood coagulation.
\end{abstract}

Key words: idarucizumab, dabigatran, antidote, gastrointestinal bleeding

Folia Cardiologica 2016; 11, 6: 554-556

\title{
Piśmiennictwo
}

1. Connolly S.J., Ezekowitz M.D., Yusuf S. i wsp. Dabigatran versus warfarin in patients with atrial fibrillation. N. Engl. J. Med. 2009; 361:1139-1151. 